تأثير قدرت يونى زئوليت بر جذب آرسنيك و عناصر ضرورى گندم درخاكهاى آلوده به جنخافزارها و سلاحهاى شيميايى

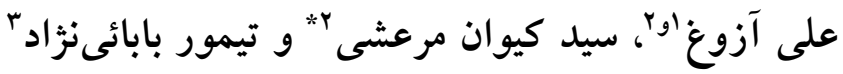

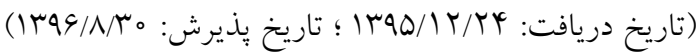

جكيده

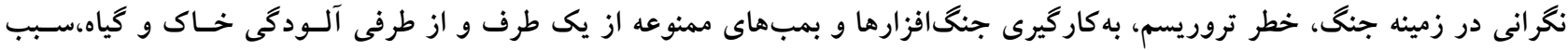

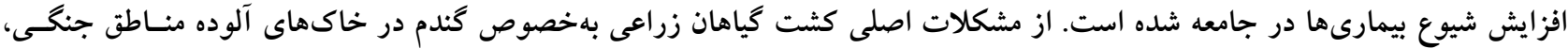

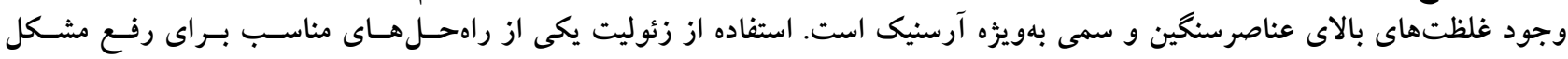

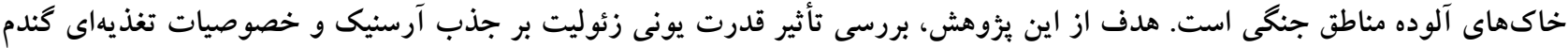

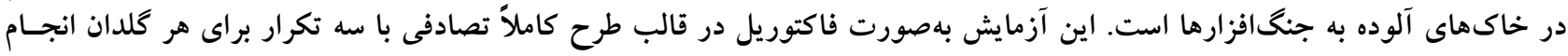

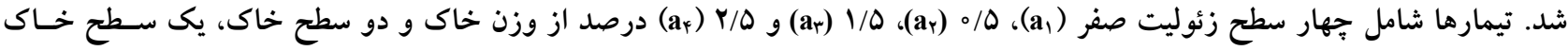

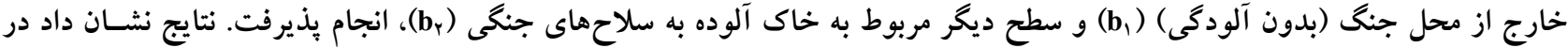

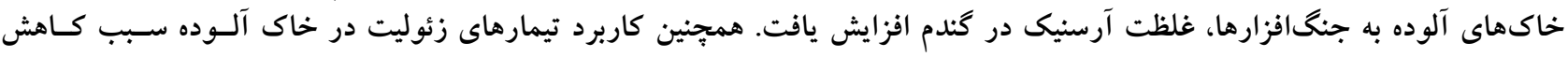

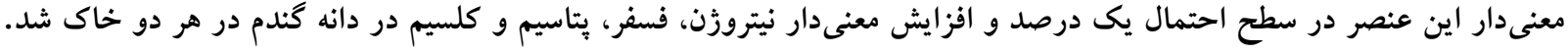

وازههاى كليدى: آرسنيك، آلودگى، جنگافزارها، زئوليت، گندم 
استرانسيم و بـاريوم (كـروه II ) در جــدول تنـاوبى هسـتند (Y).

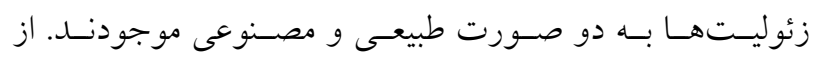

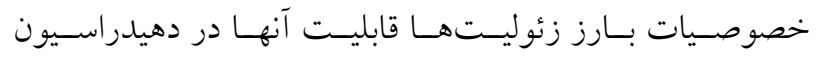

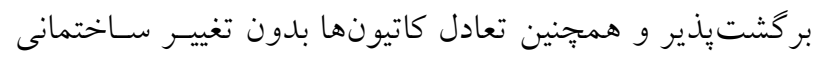

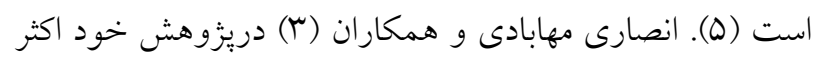

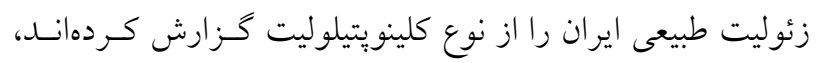

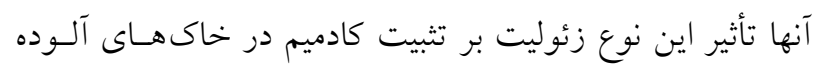

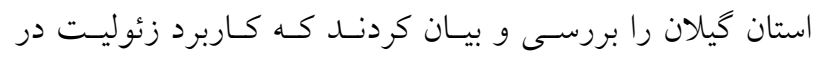

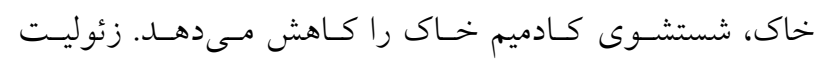

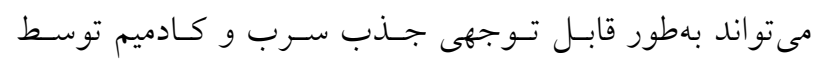

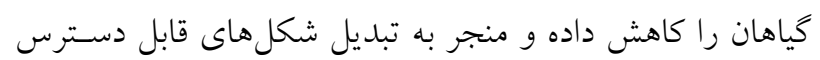

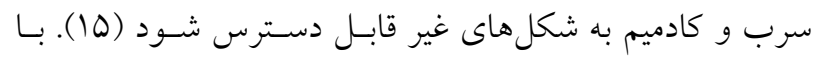

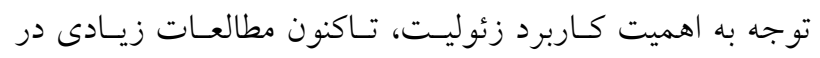

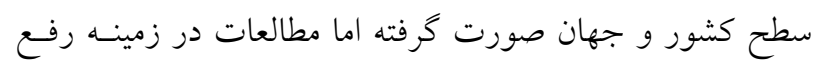
آلودكى از محصولات كشاورزى حاصل از خاكهاى آلـوده بــهـ

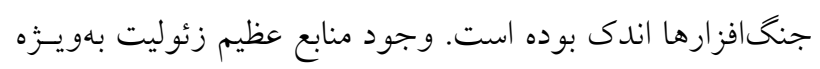

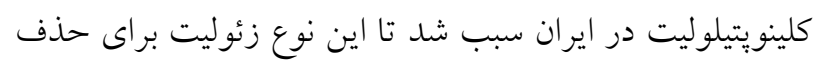

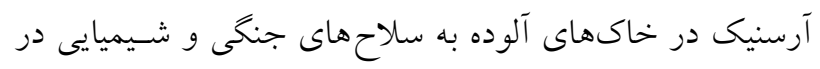

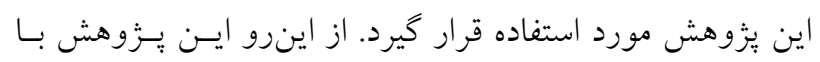

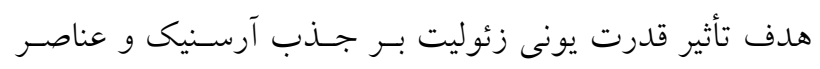
مغذى توسط كُندم در خاكهاى آلوده به انجام رسيد.

\section{مواد و روشها}

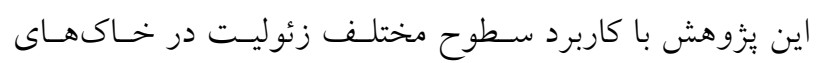

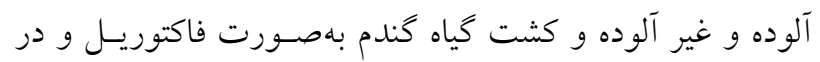

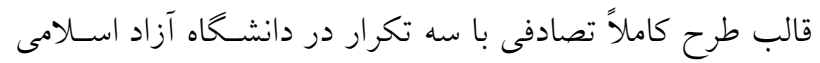

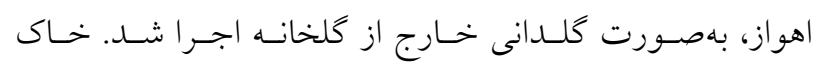

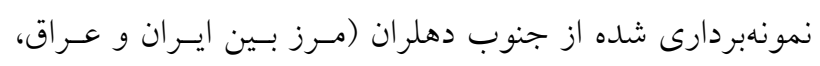

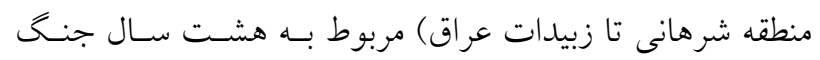

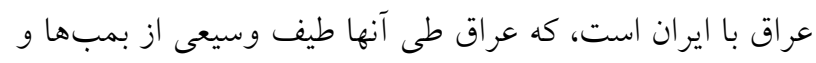

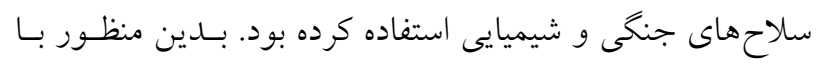

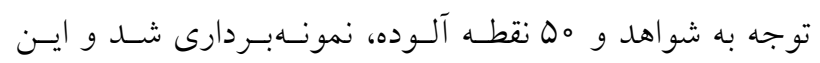

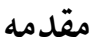

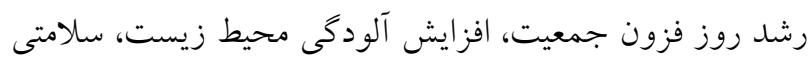

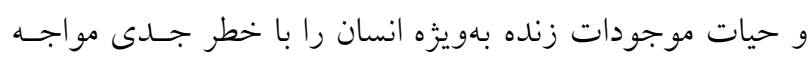
ساخته است (V). جنغ يكى از عو امل آلوده شدن محيط زيست

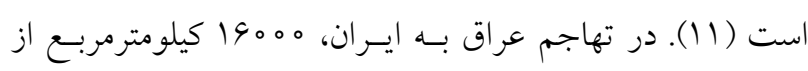

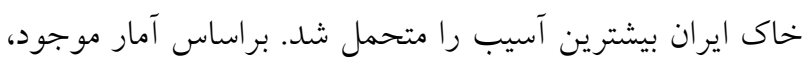

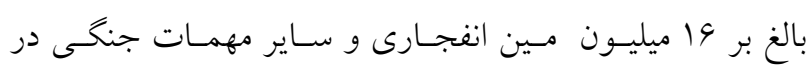

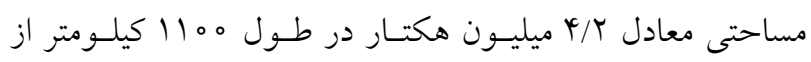

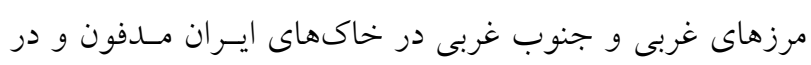

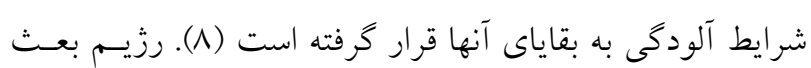

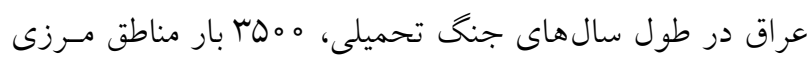

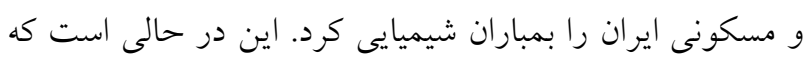

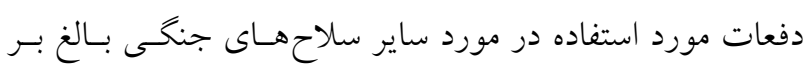

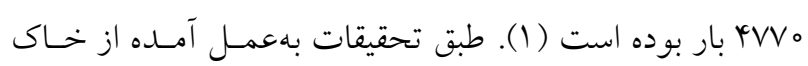

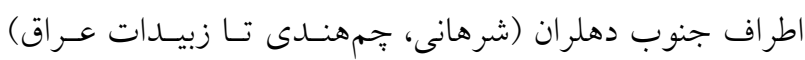

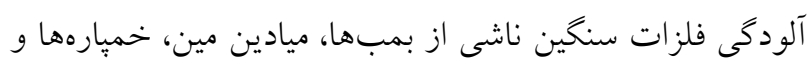

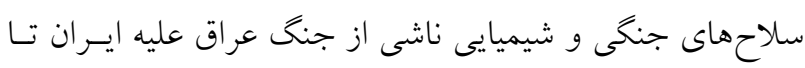

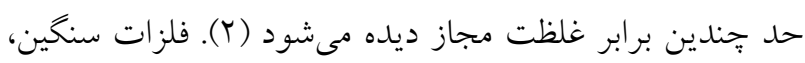

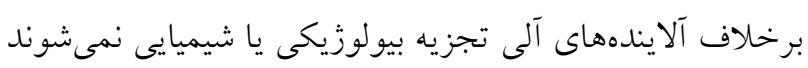

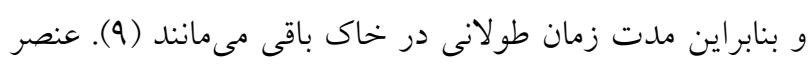

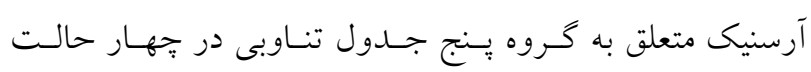

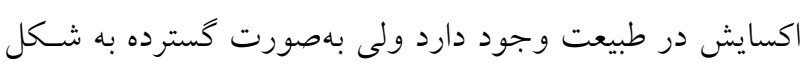

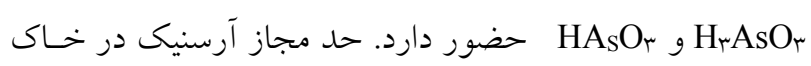

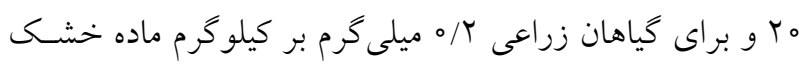

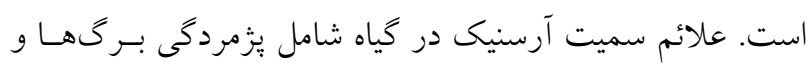

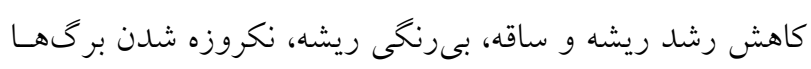

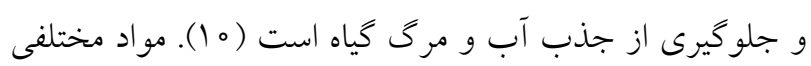

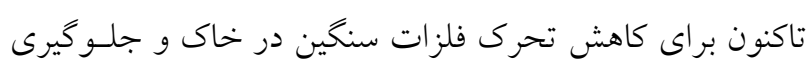

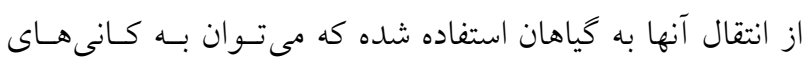
رسى بهخصوص زئوليت اشاره كرد (V).

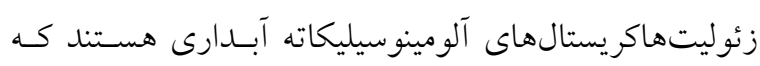

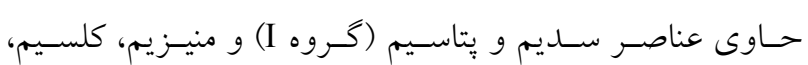




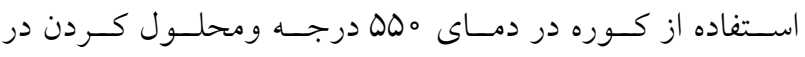

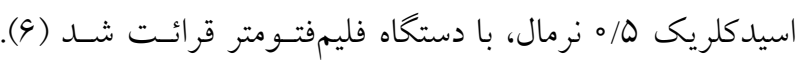

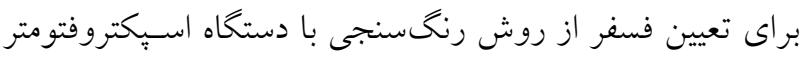

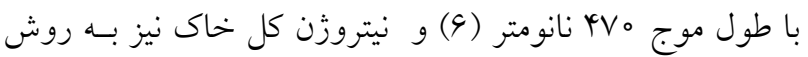

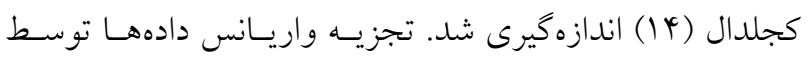
نرمافزار آمارى SAS انجام و براى مقايسه ميـانخينهـا از روش برشدهى اثر متقابل در سطح ينج درصد استفاده شد.

\section{نتايج و بحث}

برخى از خصوصيات فيزيكى و شـيميايى خـاك و زئوليـت در جدولهاى ( () و(Y) نشان داده شده اسـت. pH خـاك يكى از عوامل كنترل كننده قابليـت دسترسى فلـزات سـنخين در خـاك است. pH خاك آلوده نسبت به خاك غير آلوده اسـيدى تسر بـود. مو اد بهجا مانده از بمبهها اسـيديته خـاك را تغييـر مسىدهنـــــ و بسته به نوع مواد منفجره خاك را اسيدى يا قليايى مى كنــد (Y).

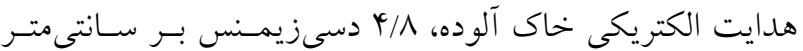
است كه در مقايسه با خاك غير آلوده كمى شورتر است. غلظت

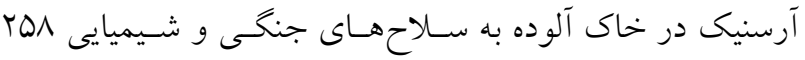

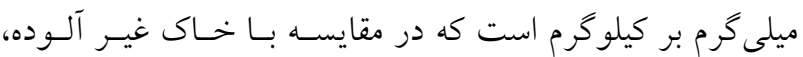

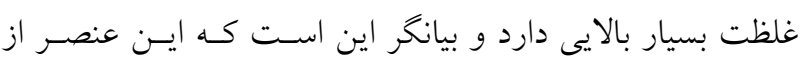

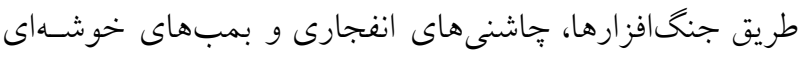

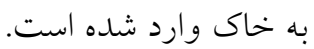

تأثير تيمارهاى زئوليت و خاك بر غلظت آرسنيك دانه

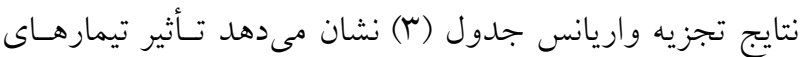
زئوليت بر كاهش جذب آرسنيك گنــدم معنسىار اسـت. نتـايج مقايسه ميانخينها (شكل () نشان مىدهد در خـاك غيـر آلـوده بهدليل غلظت يايين اين عنصر، تفاوت معنىدار ناشى از تفـاوت

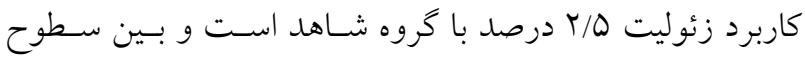

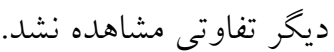

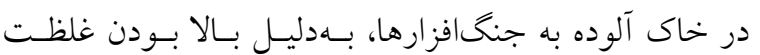

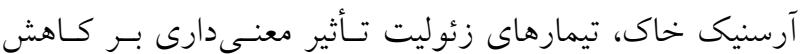

هo نمونها براى سطح خاك آلوده در نظر كرفته شد. همجنـين

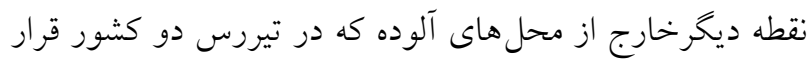

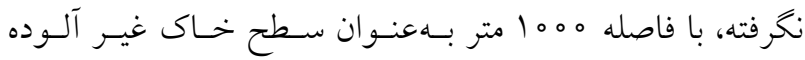

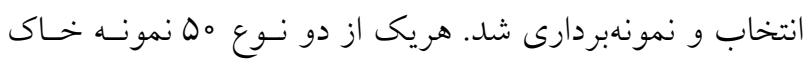
جداكانه با يكديخر مخلوط و دو نمونه خاك مركب تهيـه شـــ.

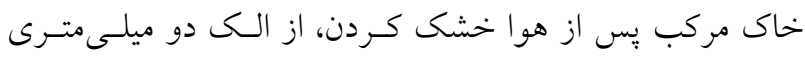

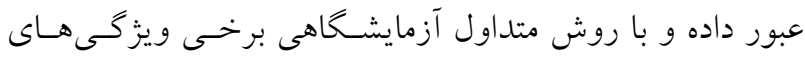

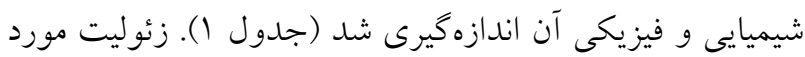

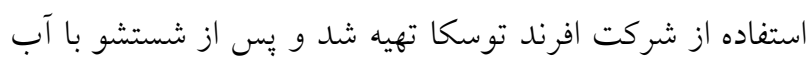
مقطر و هو ا خشك كـردن از الـى يـك ميلسىتــى عبـور داده

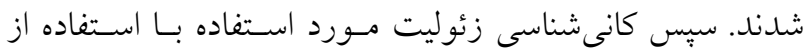

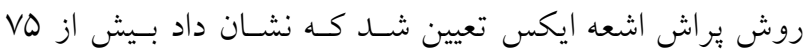
درصد زئوليت مورد اسـتفاده از كلينويتيلوليـت خـالص تشـكيل شده است. برخى از ويزّكىهـاى زئوليـت در جــدول (Y) آمــه

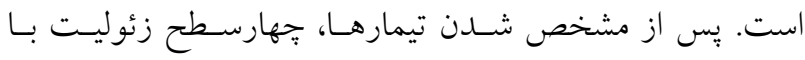

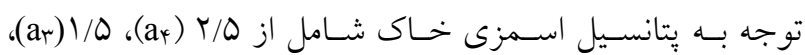

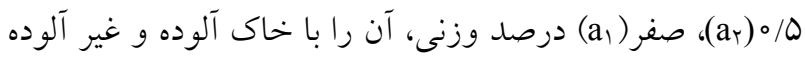

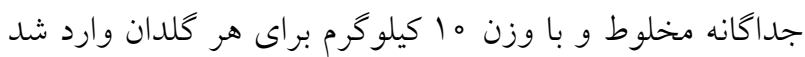

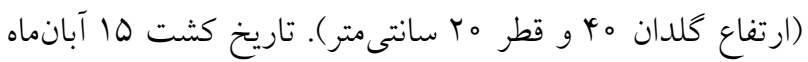

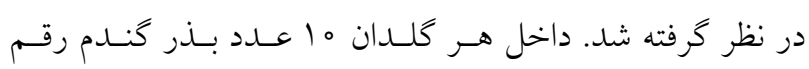

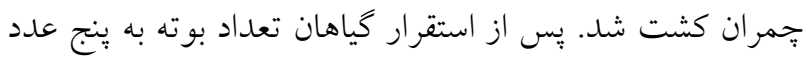

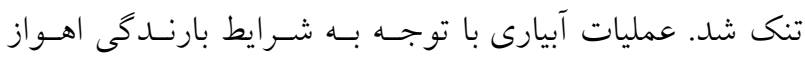

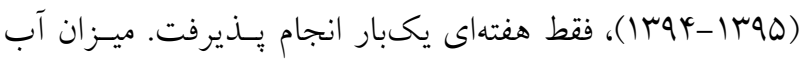

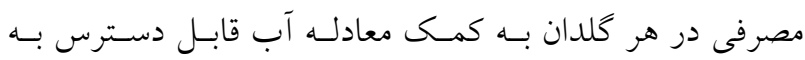

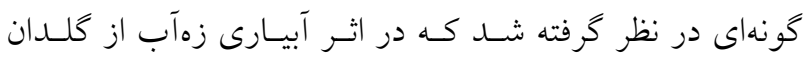

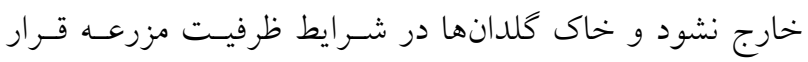

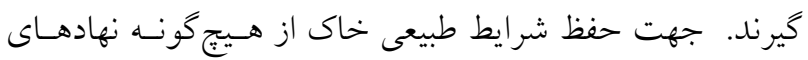

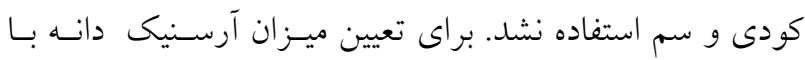

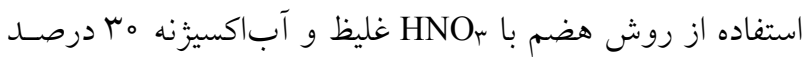
استفاده شد و غلظت اين عنصر در عصاره كياه بلوسيله دستخًاه

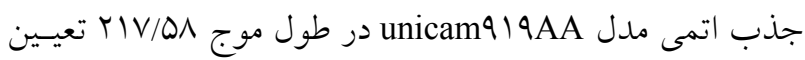
شد (9). ميزان يتاسيم و كلسيم دانهها به روش هضم خشك بـا 


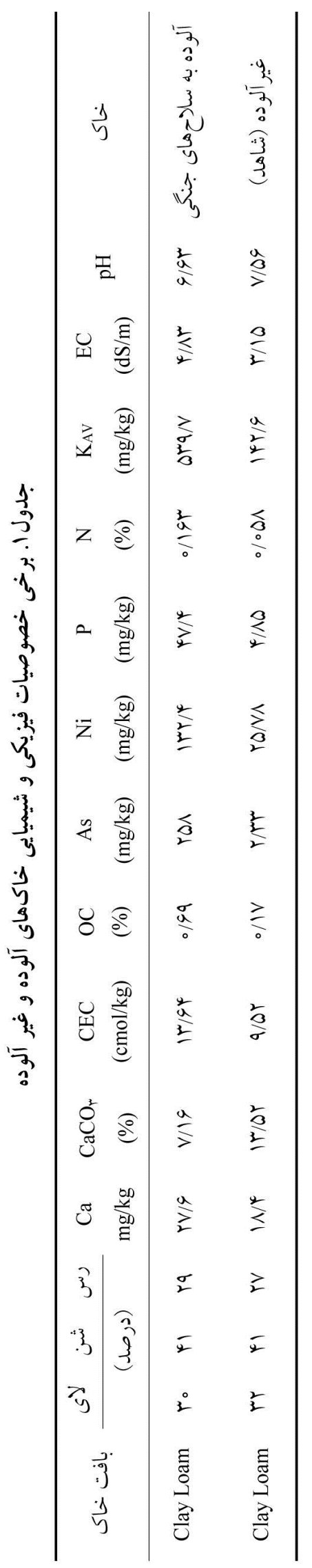




\begin{tabular}{|c|c|c|}
\hline مقدار & واحد & يار امتر \\
\hline$\Lambda / 4$ & - & $\mathrm{PH}$ \\
\hline $0 / 09$ & $\mathrm{dS} / \mathrm{m}$ & $\mathrm{EC}$ \\
\hline IVo & $\mathrm{cmol} / \mathrm{kg}$ & CEC \\
\hline $99 / 0$ & درصد & $\mathrm{SiO}_{r}$ \\
\hline $11 / 11$ & درصد & $\mathrm{Al}_{r} \mathrm{O}_{r}$ \\
\hline $1 / \mu$ & درصد & $\mathrm{Fe}_{r} \mathrm{O}_{r}$ \\
\hline $0 / Y 1$ & درصد & $\mathrm{TiO}_{\curlyvee}$ \\
\hline$Y / \wedge \Delta$ & درصد & $\mathrm{CaO}$ \\
\hline$\circ / V Y$ & درصد & $\mathrm{MgO}$ \\
\hline$\circ / 0$ & درصد & $\mathrm{Na}_{r} \mathrm{O}$ \\
\hline$r / T$ & درصد & $\mathrm{K}_{\mathrm{r}} \mathrm{O}$ \\
\hline
\end{tabular}

\begin{tabular}{|c|c|c|c|c|c|c|}
\hline كلسيم & يتاسيم & فسفر & ن نيتروزن & آرسنيك & درجه آزادى & منبع تغيير \\
\hline$\circ / 01 V^{* *}$ &.$/ 010^{* *}$ & $\circ / \circ \circ Q^{* *}$ & $\circ / \mathrm{VIV} \mathrm{V}^{* *}$ & $4 / 900^{* *}$ & $r$ & زئوليت \\
\hline$\circ / 0 \circ \varphi^{* *}$ & $\circ / \circ 9 r^{* *}$ & $0 / Y Y Y^{* *}$ & $\Gamma / q^{* * *}$ & | I / & 1 & خاى \\
\hline$\circ / 001^{*}$ & $\circ / \circ \circ 0^{\mathrm{ns}}$ & ००००ns & $\circ / 9 \circ r^{* *}$ & 1/4Mr"** & r & خاى × زئوليت \\
\hline ०/००० & \%००० & D/GYY & $\circ / \circ \circ \circ \Delta$ & $0 / 001$ & 19 & خطا \\
\hline
\end{tabular}

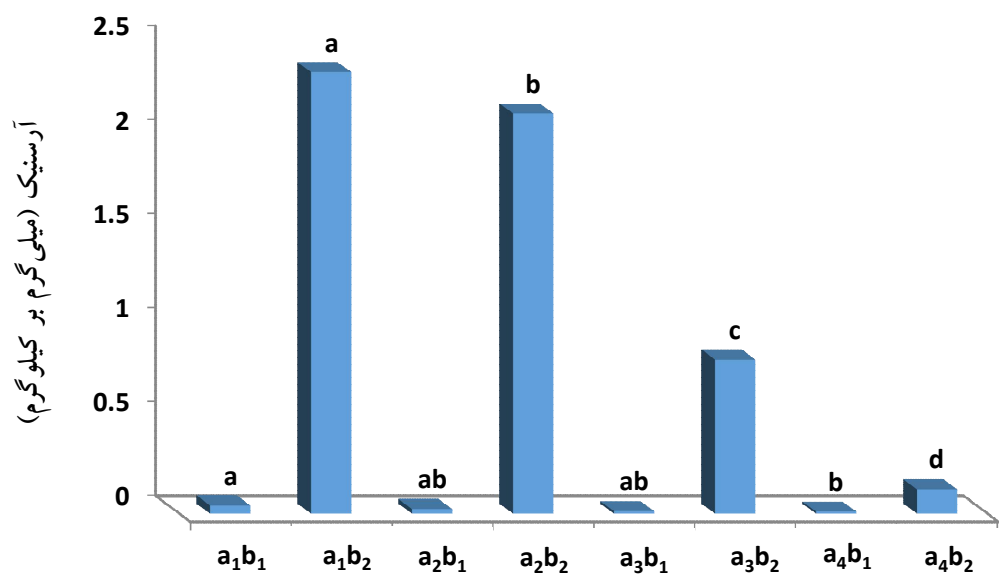

شكل l. اثر تيماهاى خاك ( مقدار آرسنيك دانه. ميانكين تيمارهايى كه داراى حروف مشابهى هستند، در سطح بنج درصد ازلحاظ آمارى اختلاف معنىدارى با همديخر ندارند. 


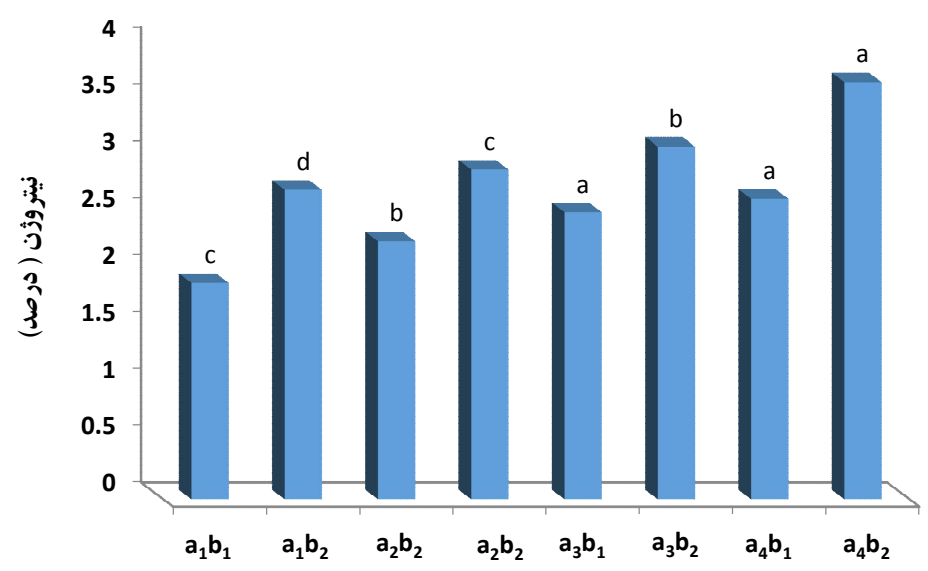

شكل r. اثر تيمارهاى خاك (b) غير آلوده و

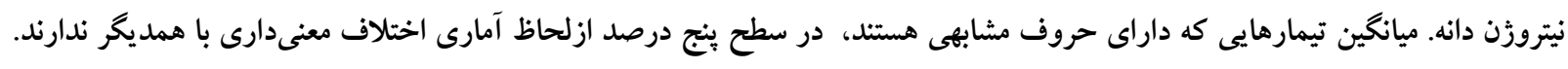

تأثير تيمارهاى زئوليت ونوع خاك بر درصد نيتروزن دانه

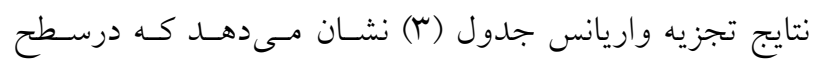

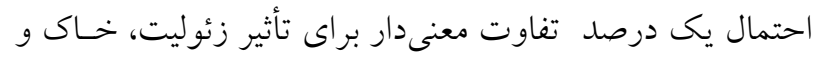

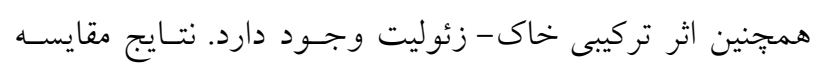

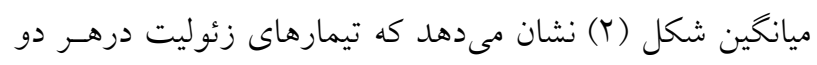

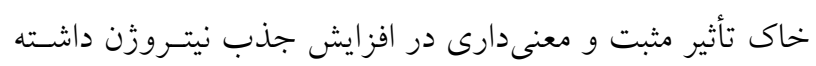

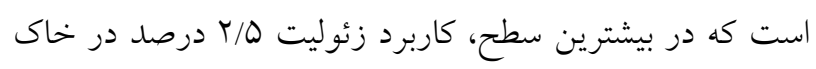

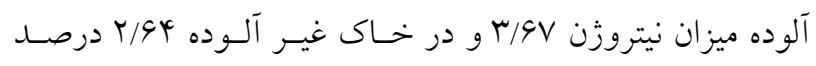

$$
\text { بود. }
$$

بيشترين جذب نيتروزن در گندم مربوط به تيمار خاك آلوده

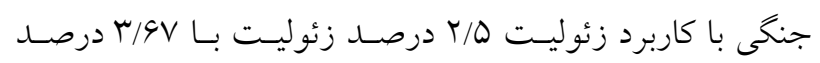

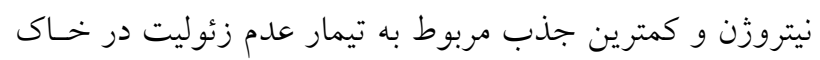

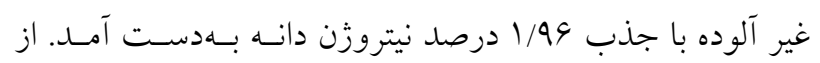
دلايل معنى دار شدن نيتروزن كندم تحت كاربرد سطوح مختلف

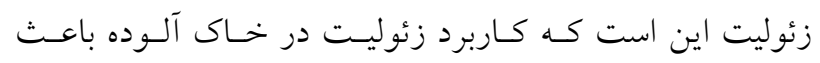

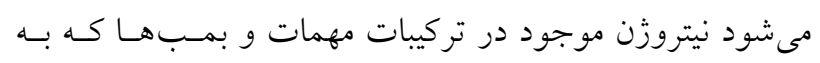

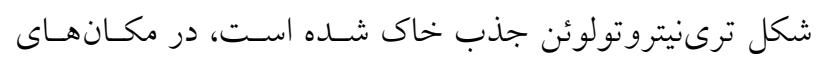

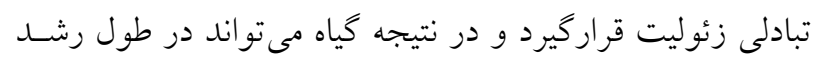

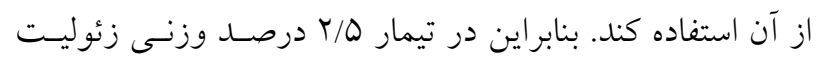

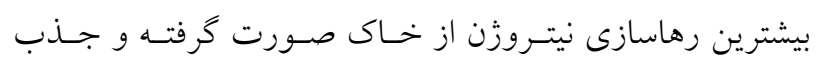

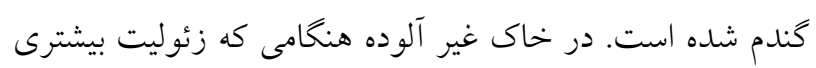

غلظت آرسنيك در گياه نشان داد. نتايج نشان مىدهد با بيشترين

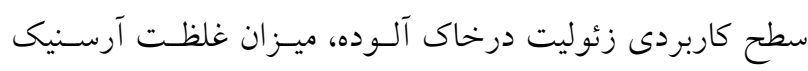

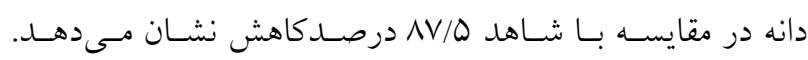
بيشترين جذب آرسنيك مربوط به خاك آلـوده بـا عـدم كـاريرد

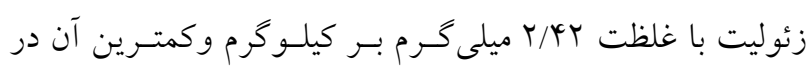

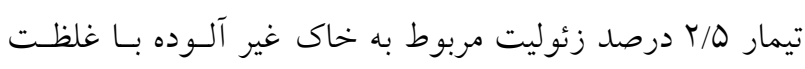

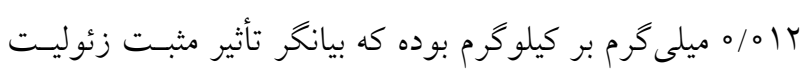
در رهاسازى عناصر مفيد و كـاهش ايسن عنصـر سـمى در كيـاه

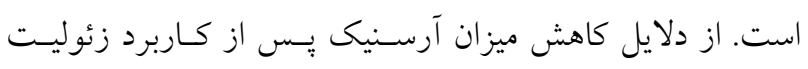

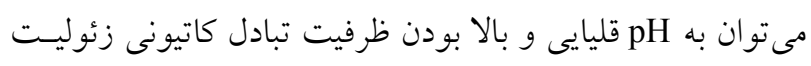

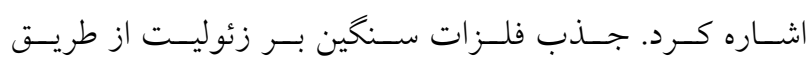

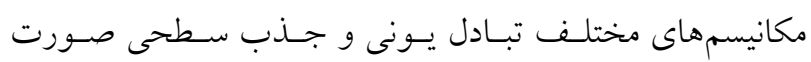

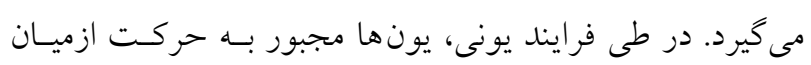

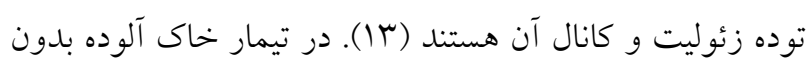

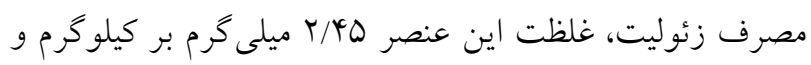

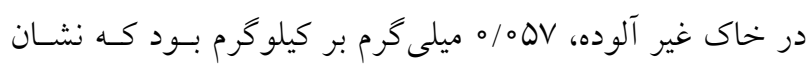

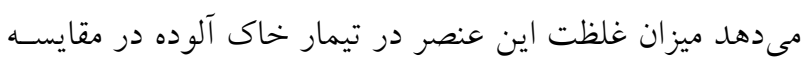

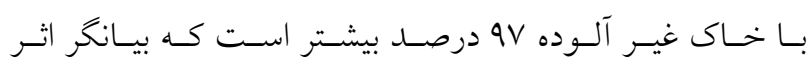

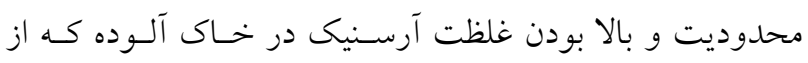

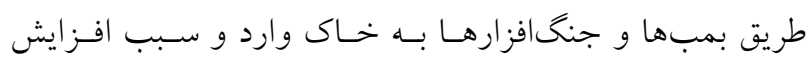
جذب آن در ريشه وسبس به گياه منتقل شده است. 


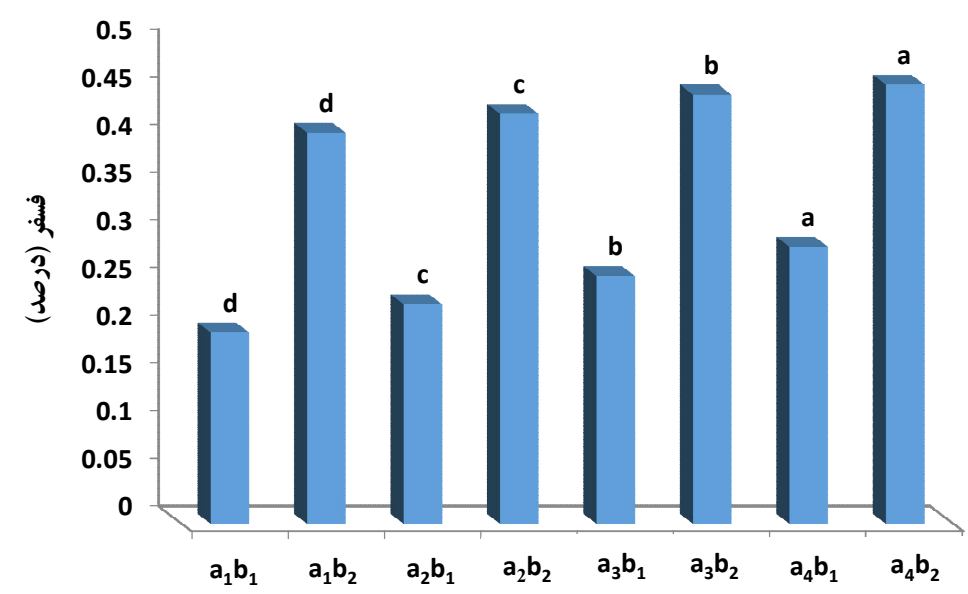

شكل r. اثر تيمارهاى خاك (b/ לير آلوده و

فسفر دانه. ميانگين تيمارهايى كه داراى حروف مشابهى هستند، در سطح بنج درصد ازلحاظ آمارى اختلاف معنىدارى با همديخر ندارند.

بيشترين فسفر دانه در تيمار خاى آلـوده جنكسى بـا كـاربرد

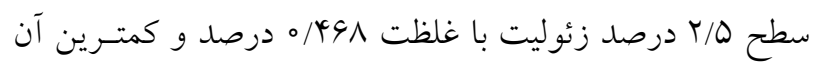

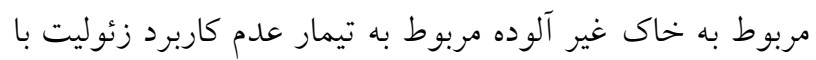

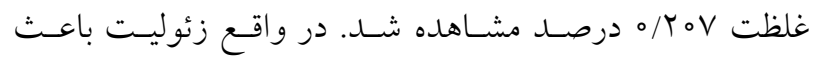
رهاسازى فسفر تثبيت شده و افزايش حلاليت فسفر محلـول در

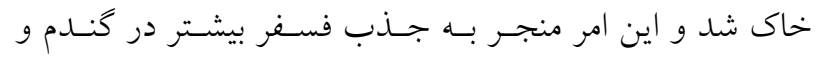

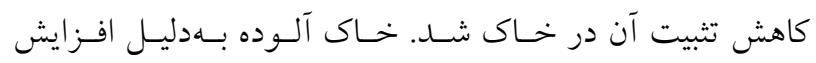

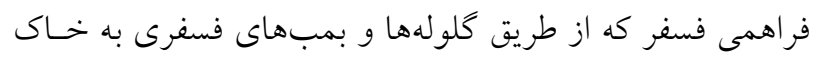
وارد شده، ميزان غلظت بيشترى از فسفر در مقايسه با خاك غير

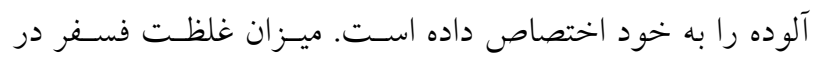

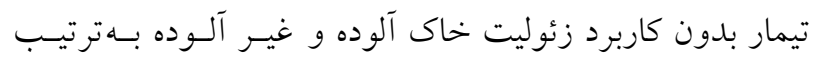

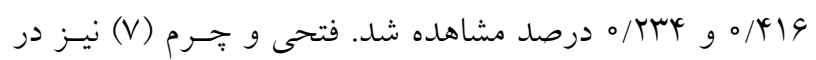

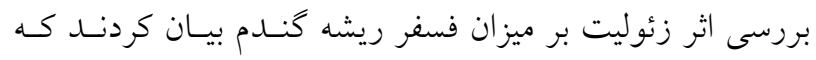

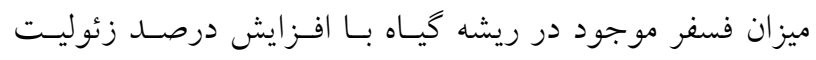
كاربردى به خاك افزايش مىيابد.

تأثير تيمارهاى زئوليت و نوع خاك بر درصد يتاسيم دانه

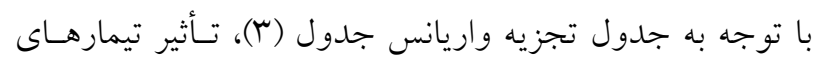

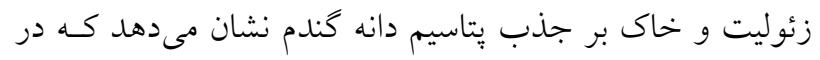

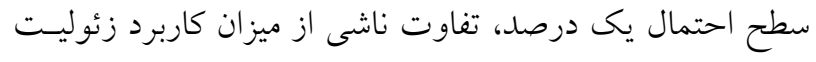
معنى است است نمودار مقايسه ميانكين نشان مىدهد كه در خاك
استفاده مىشود، با افزايش جذب نيتروزن و آسميلاسيون آمـونيم،

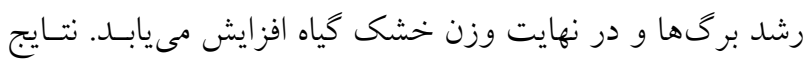

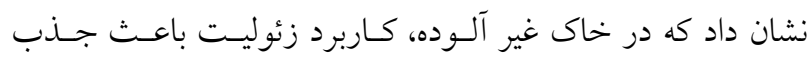

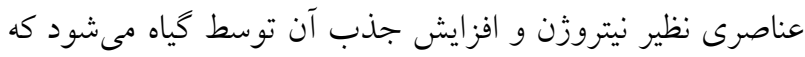

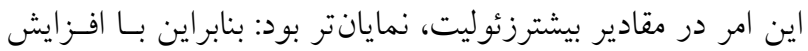

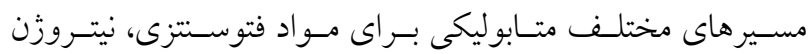
بيشترى به دانه منتقل مىشود. در خاك آلوده و غير آلـوده (تيمـار

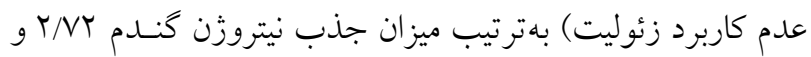
1/99 درصد بود كه نشاندهنده تفاوت نوع خاك رنوب از لحاظ تركيب

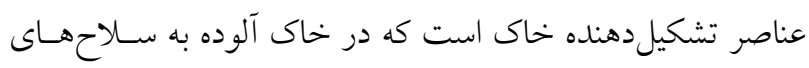

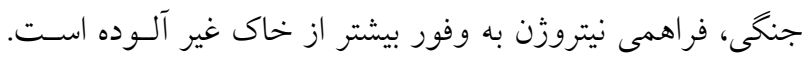

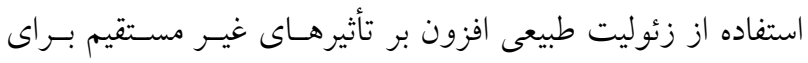

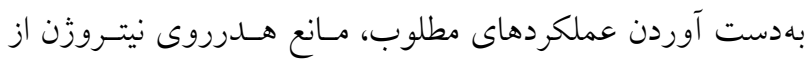

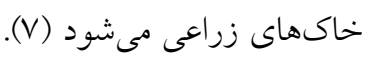

تأثير تيمارهاى زئوليت و نوع خاك بر درصد فسفر دانه

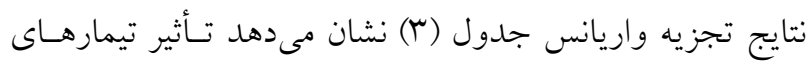

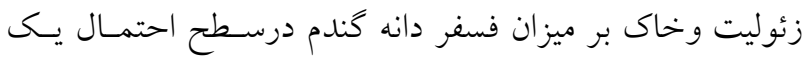

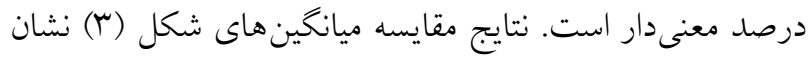
مى دهد كه زئوليت در هر دو خاك، اثر مثبت در ميـزان افـزايش جذب فسفر دانه در هر دو خاك داشته است. 


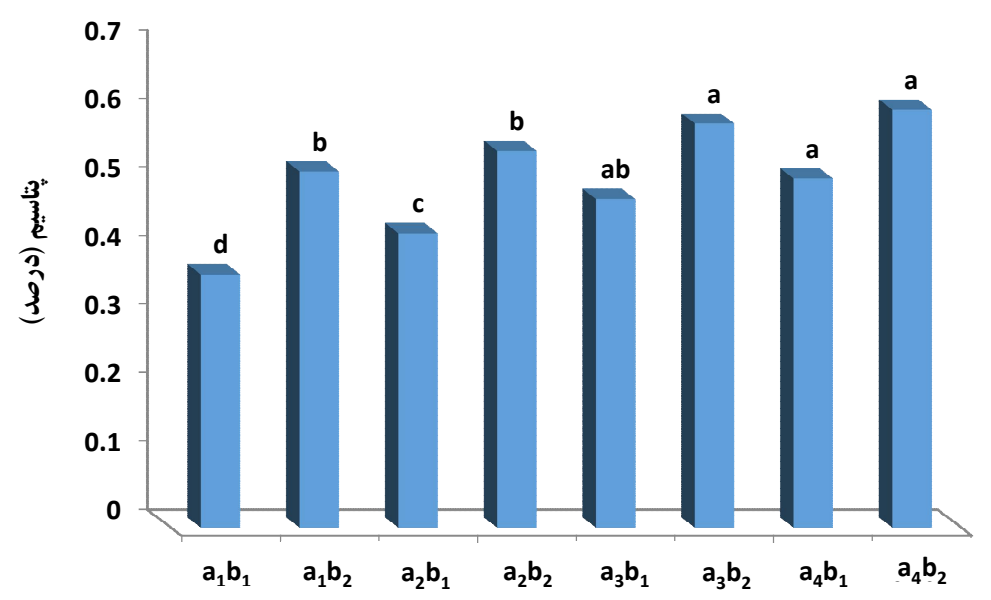

شكل F. اثر تيمارهاى خاك (b) غير آلوده و

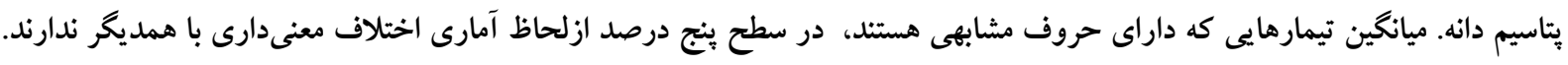

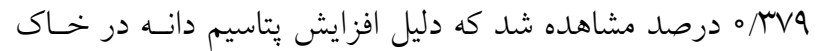

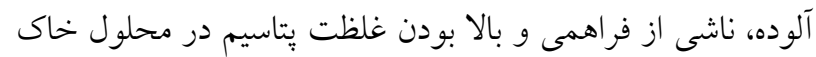

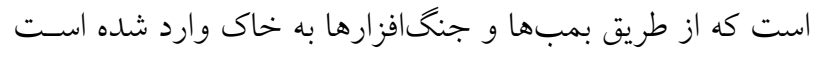
و سبب افزايش غلظت يتاسيم خاك شده است (جدول ().

تأثير تيمارهاى زئوليت و نوع خاك بر كلسيم دانه

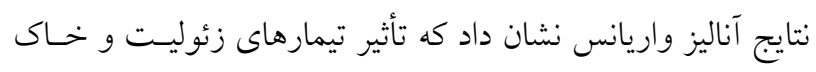

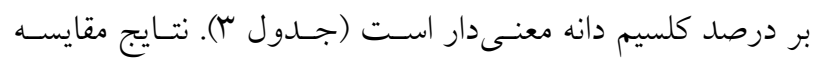

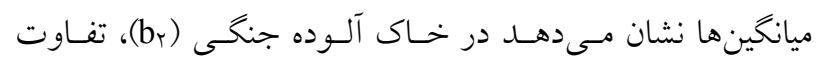

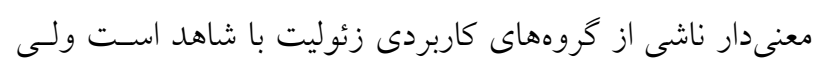

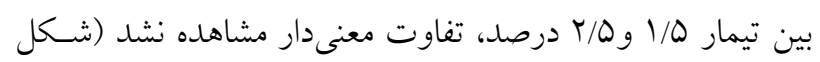

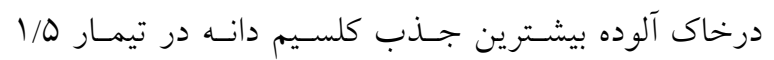

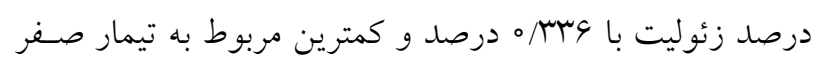

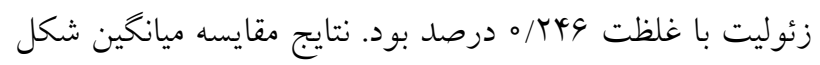

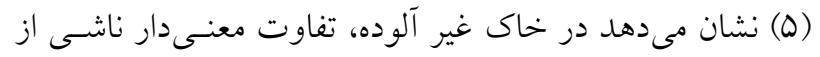

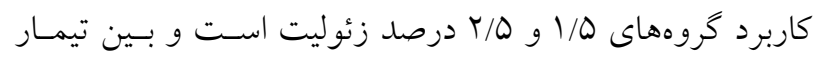

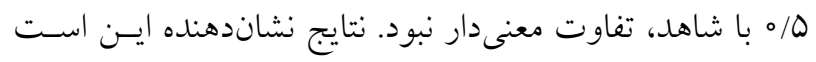

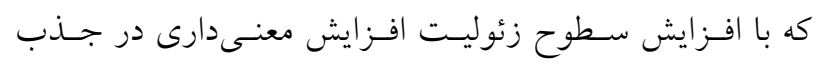

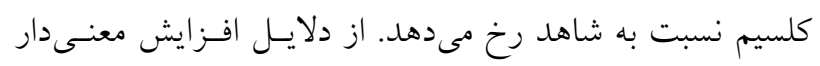

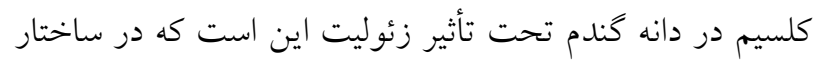

آلوده به جنگ افزارها، تفاوت معنىدار ناشى از كاربرد تيمار T/D

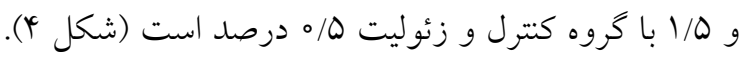

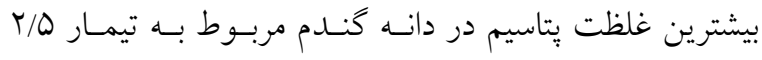

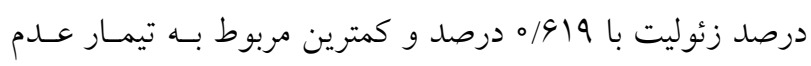

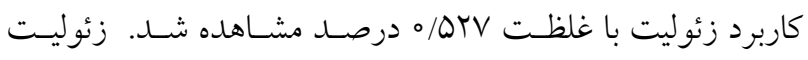

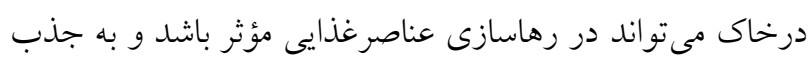

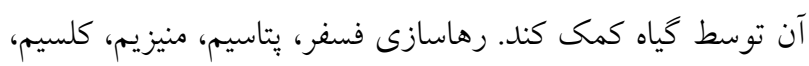

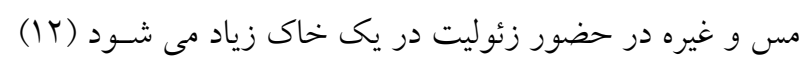

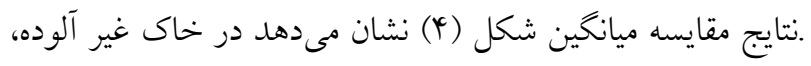

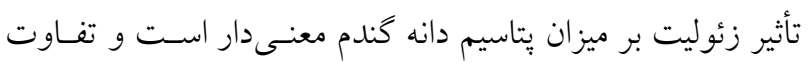
معنى دارى بين تيمار شاهد با ساير تيمارهاى زئوليت وجـود دارد.

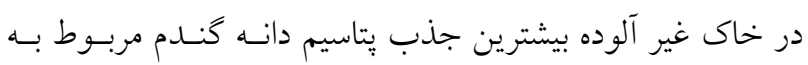

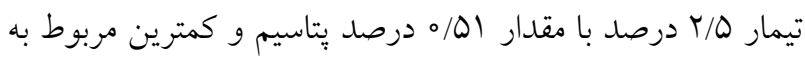

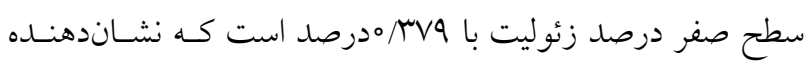
تاثير مثبت زئوليت بر افزايش بت بتاسـيم خـاك و در نتيجـهـ افـزايش يتاسيم دانه است. زئوليـت بـهـعنـوان يـك كـود يتاسـيم اسـتفاده

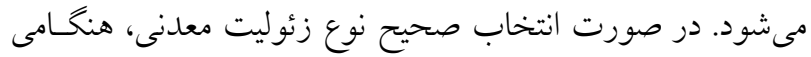

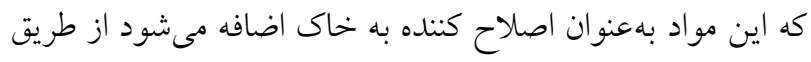
افزايش فراهمى طولانىمدت عناصر غذايى، به بهبـود رشـــ كيـاه

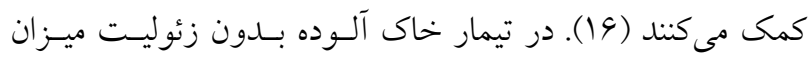

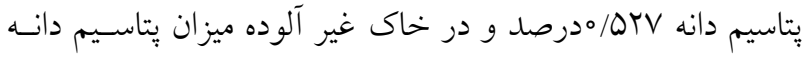




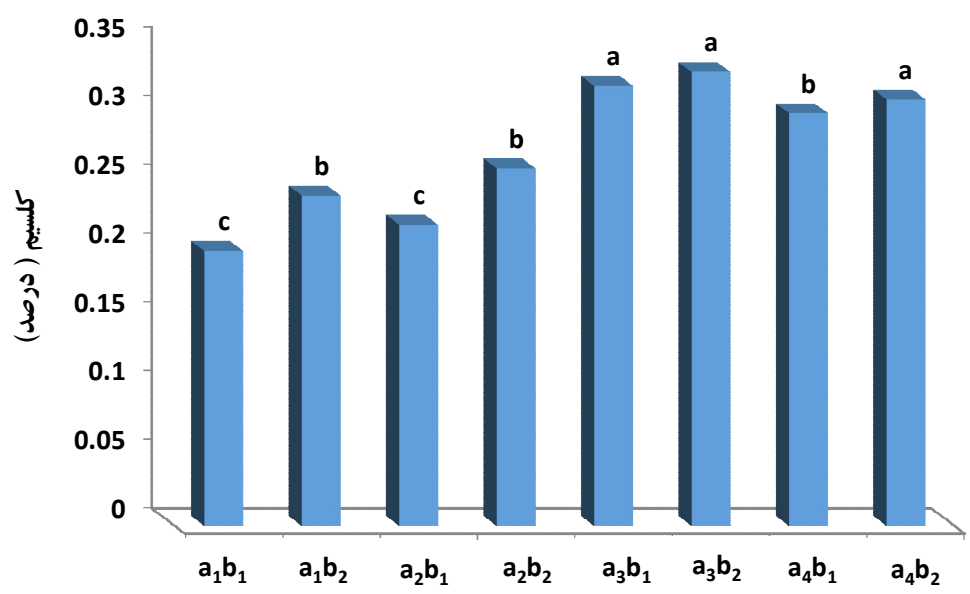

شكل ه. اثر تيمارهاى خاك (

كلسيم دانه. ميانگين تيمارهايى كه داراى حروف مشابهى هستند، در سطح بنج درصد ازلحاظ آمارى اختلاف معنىدارى با همديخر ندارند.

يافته است. درسطح كاربرد زئوليت ه/ 1 درصد ميزان كلسيم دانه

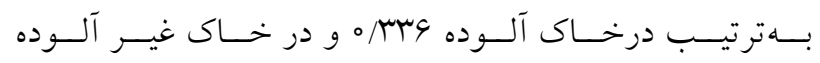

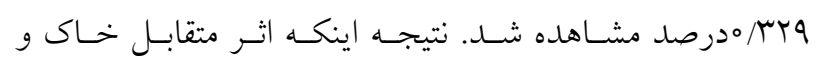
زئوليت در سطح بنج درصد معنىدار است. در تيمار خاى آلوده

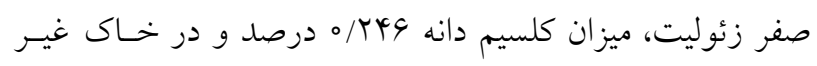

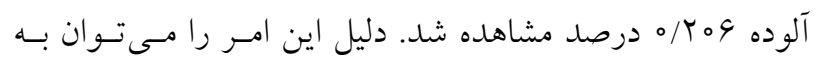
جذب ترجيحى بعضى از كاتيونها توسط زئوليـت و در نتيجـه آزاد شــن كلسـيم از ايسن كـانى دانسـت. همجزتسين بـا كـاربرد زئوليت، كميلكسهاى كلسيم كه با عناصرى مثل فسفر و عناصر ميكرو در خاك وجود دارند، شكسـته شــده و كلسـيم آنهـا آزاد مىشود. فتحى و جرم (V) نيز در تحقيق خود بيان كردند كـه بـا كاربرد زئوليت در خاك، غلظت عناصر ضرورى نظير كلسيم در بافتهاى گياهى افزايش يافته است.

\section{نتيجه گيرى}

نتايج نشان داد خاكهاى آلوده به جنگ افزارهـا بـهدليـل وجـود

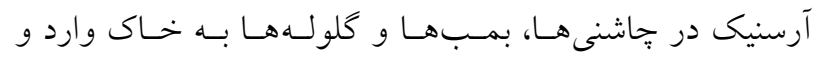

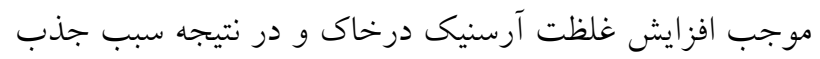

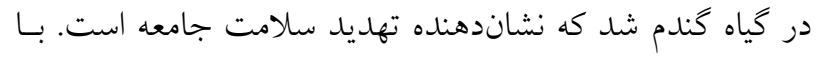
كاربرد كانى زئوليت، غلظت و سميت اين عنصر بهطور معنىدار

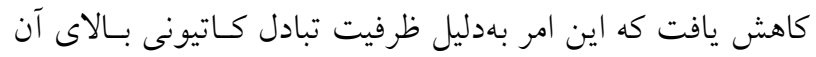

زئوليت كاتيونهاى بازى نظيـر كلسـيم، وجـود دارد كـه سـبب افزايش كلسيم خاك و در نتيجه سبب افزايش كلسيم دانه شـده است ـ شكل مولكولى كلسيم در زئوليت بهصورت CaO اسـت كه مقدار آن ه/A/ درصد است (جدول Y). درخاك غيـر آلـوده بيشترين جذب كلسيم دانه در تيمار ه/ ا درصد زئوليت باغلظت qr/\% درصد و كمترين جذب با عدم كاربرد زئوليت با غلظـت

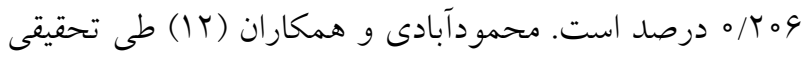
بيان كردند كه افزودن زئوليت به خاك غير آلوده موجب افزايش عناصر غذايى مانند ازت، فسفر، يتاسيم، كلسـيم، آهـن، منخخـز، مسس و روى در بافـت كيـاهى مسىشـود. زئوليـت داراى اثــر حاصلخيزى كاتيونى سودمند است كه مسى تـوان آن را بـهـعــوان كود معدنى و نياز تغذيهاى در رشد كياه با كاربرد سطوح بيشـتر مورد استفاده قرار داد (Y). همجينين نتايج نشـان داد كـهـهـم در

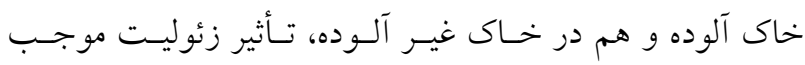
افزايش معنى دار كلسيم دانه شده است. بيشـترين مقـدار جـــب إبـ كلسيم در خاك آلوده در تيمار ه/ آدرصــ زئوليـت بـا غلظـت 4سس/ درصد و كمترين آن مربوط به تيمـار صـفر زئوليـت در

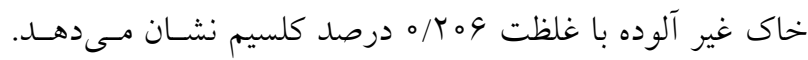
نتايج نشان مىدهد كه در وضعيت كاربردى زئوليت اه درصد، به شكل مطلوب ميزان كلسيم دانـه افـزايش داشـته و در سـطح بالاتر بهدليل رقابت كلسيم با يتاسيم، ميزان كلسيم دانـه كـاهش 
سبب بهبود حاصلخيزى خاك و در نتيجه افزايش جذب اين دو عنصر در دانه گُندم در هر دو خاص شيرى
بود. در اين آزمايش زئوليت با رهاسازى نيتروزن و فسفر منجـر

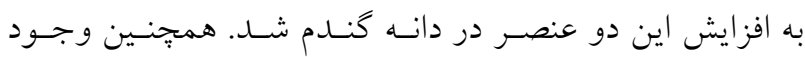

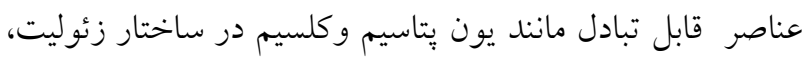

$$
\begin{aligned}
& \text { منابع مورد استفاده }
\end{aligned}
$$

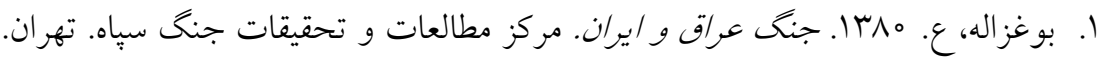

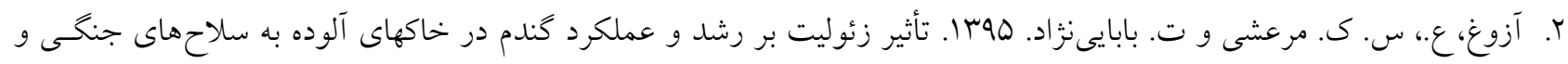

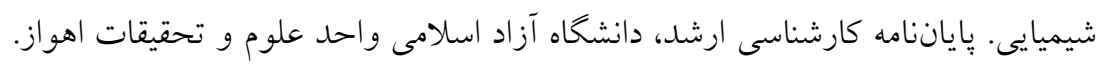

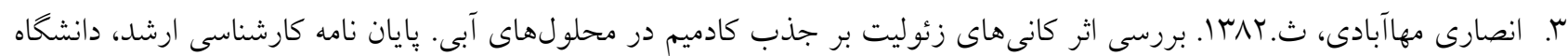

$$
\text { كشاوزى صنعتى اصفهان. }
$$

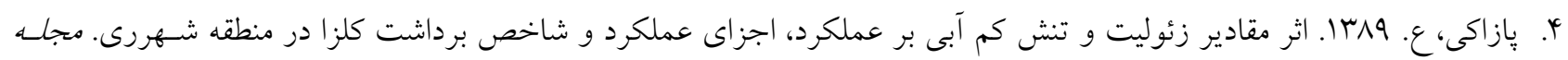

$$
\text { زراعت و اصلاح نباتات } 9 \text { (1): IV-19. }
$$

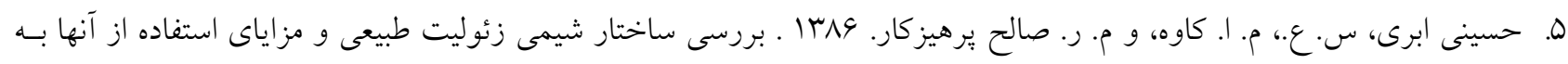

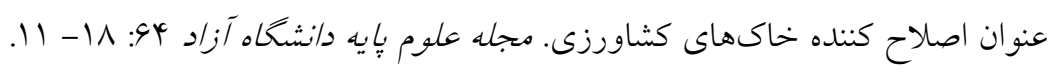

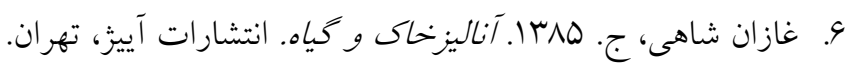

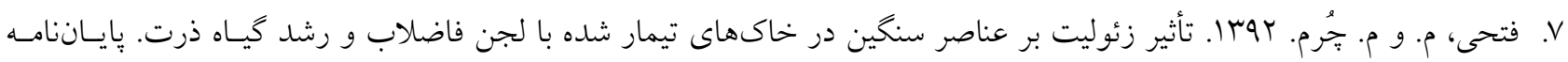

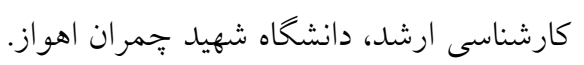

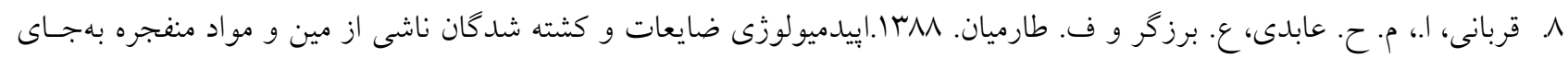

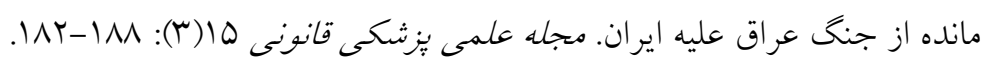

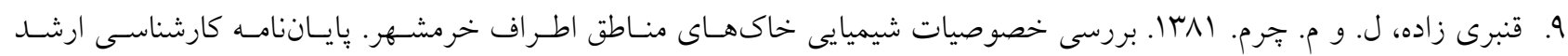

$$
\text { دانشكده كشاورزى شهيد جممران، اهواز. }
$$

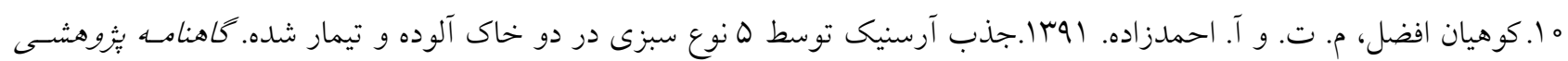

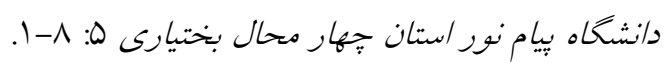

11. Leaniny, J. 2000. Environmental and health: Impact of war. CAMJ 163(9): 57-61.

12. Mahmoodabadi, M. R., F. Abdi, E. Adhami and G. H. Hadarbadi. 2008. Effects of zeolite application cadmium toxicity, growth, nodulation and chemical composition of soybean. In: Proceeding of the Iran International Zeolite Conference. Tehran.

13. Ming, D. W. and F. A. Mumpton. 1989. Zeolites in Soils. PP. 873-909. In: J. B. Dixon and S. B. Weed. Minerals in Soil Environments (2 $2^{\text {nd }}$ Edition). SSSA. Madison, Wisconsin.

14. Page A. L., R. H. Miller and D. R. Keeney. 1982. Methods of Soil Analysis, Part 2, $2^{\text {nd }}$ ed. American Society of Agronomy, Madison, Wisconsin.

15. Shi, W. Y., H. B. Shao and M. A. DuS. 2009. Progress in the remediation of hazardous heavy metal - polluted soils by natural zeolite. Journal Hazaradousmater 170: 1-6.

16. Polat, E., M. Karaca, H. Demir and A. Onus. 2004. Use of natural zeolite (clinoptilolite) in agriculture. Journal of Fruit and Ornamental Plant Research 12: 183-189. 


\title{
The Effect of lonic Strength Zeolite on the Adsorption of Arsenic and Some Essential Nutrients for Wheat in Contaminated Soils by Munitions and Chemical Weapons
}

\author{
A. Azogh ${ }^{1,2}$, S. K. Marashi2 ${ }^{*}$ and T. Babaeinejad ${ }^{3}$
}

(Received: March 14-2017 ; Accepted: November 21-2017)

\begin{abstract}
The concern about the war and the threat of terrorism and weapons application and prohibited weapons is growing; on the other hand, the contamination of soil, plant and disease outbreaks in the community is increasing. The main problem with crops, especially wheat in the contaminated soils of war zones, are associated with the high concentrations of heavy metals and toxic things, especially arsenic. Zeolite is one of the solutions to the problem of contaminated soils in war affected areas. The aim of this study was to determine the effect of the ionic strength of zeolite on the adsorption of arsenic and nutritional properties of wheat in contaminated soils including weapons. The experiment was carried out in a factorial arrangement involving a randomized complete design with three replications. Treatments included four levels of zeolite $2.5\left(\mathrm{a}_{4}\right), 1.5\left(\mathrm{a}_{3}\right), 0.5\left(\mathrm{a}_{2}\right), 0\left(\mathrm{a}_{1}\right)$ percent of the weight of the soil and two soil recourses, one obtained from out of the war zone (without contamination) $\left(b_{1}\right)$ and other one was from the contaminated soil to weapons $\left(b_{2}\right)$. The results showed that soils contaminated by weapons increased the concentrations of arsenic in wheat. Also, with the application of Zeolite in the contaminated soil treatments, there was a significant reduction at $1 \%$ level and a remarkable increase in nitrogen, phosphorus, potassium and calcium in the wheat grain in both soils.
\end{abstract}

Keywords: Arsenic, Pollution, Weapons, Wheat, Zeolite

1. Department of Agronomy, Khuzestan Science and Research Branch, Islamic Azad University, Ahvaz, Iran.

2. Department of Agronomy, Ahvaz Branch, Islamic Azad University, Ahvaz, Iran.

3. Department of Soil Science, Ahvaz Branch, Islamic Azad University, Ahvaz, Iran.

*: Corresponding Author, Email: marashi_47@yahoo.com 